\author{
Case Study \\ www.ijrap.net
}

\title{
A CASE STUDY TO EVALUATE THE EFFICACY OF PANCHAKOLA UDAKA AND AAROGYAVARDHINI VATI IN GRAHANI DOSHA WITH SPECIAL REFERENCE TO IRRITABLE BOWEL SYNDROME
}

\author{
Anjali Goyal * \\ Associate Professor, Department of Samhita and Siddhanta, Punjab Ayurveda Medical College and Hospital (PAMCH), \\ Morjandakhari, Sriganganagar, Rajasthan, India \\ Received on: 05/09/19Accepted on: 18/10/19
}

\begin{abstract}
*Corresponding author
E-mail: anjalitonk.84@gmail.com
\end{abstract}

DOI: 10.7897/2277-4343.1006132

\begin{abstract}
Irritable bowel syndrome (IBS) is a gastrointestinal tract functional disorder leading to diarrhea/constipation. Prevalence of IBS has been ranging between $3 \%$ and $22 \%$, and usually found in the age group of $15-50$ years. Studies have shown antibiotics and anti-spasmodic users at a greater mortality risk so; need to complement the existing treatment options. IBS can be co-related with Grahani Doshain Ayurveda. The Aim of this study is to evaluate the efficacy of Panchakola Udaka (medicated drinking water with Panchakola powder) and Arogyavardhini Vati in Grahani Dosha IBS using standardized outcome measures. A male patient aged 40 years came with the chief complaints of Atishrastavibaddha Mala, (at once well-formed stool, at once loose stool), Tiktamla udgara (bitter and sour belching), Aruchi (tastelessness), Bharakshaya (weight loss) of $20 \mathrm{~kg}$, Balakshaya (loss of physical strength), Trishna (thirst) and Parvaruk (pain in small joints), since 2 years. Patient was given medicines orally i.e. Panchakola Udakain many doses of $250 \mathrm{ml}$, in place of normal water, whenever he felt thirsty; Aarogyavardhini Vatiin dose of 2 tablets of $250 \mathrm{ml}$ B.D. after meal with Panchakola Udaka for 1 month. Gradation of all signs and symptoms was used to evaluate response to therapy. Data were collected at baseline, $15^{\text {th }}$ day, and end of the treatment (day 30). There was significant relief in all symptoms of Grahani Dosha $\sim$ IBS, with no side effects. Hence it is concluded that Panchakola Udaka along with Aarogyavardhini Vati are encouragingly effective in Grahani Dosha IBS.
\end{abstract}

Keywords: Irritable Bowel Syndrome; Grahani Dosha; Panchakola Udaka; Aarogyavardhini Vati and Ayurveda.

\section{INTRODUCTION}

Irritable bowel syndrome (IBS) is a functional disorder of gastrointestinal tract without any structural defect with symptoms like altered abdominal habit, abdominal pain and bloating, feeling of incomplete defecation, passage of mucus in stool. Activity of bowel is increased or decreased in such a way that it leads to diarrhea or constipation. Prevalence of IBS has been ranging between $3 \%$ and $22 \%$ in the community with wide variations between countries. ${ }^{1}$ The disorder is usually found in the age group of 15-50 years and may also occur in children and elderly.

There is a need to complement the existing treatment options like antacids, antispasmodic and antibiotics. So, in this report we tried to find out solution for this problem. IBS can be correlated with Grahanidosha in Ayurveda which means diseases due to malfunctioning of Grahani (duodenum). There is need to know normal functions of Grahani for understand Grahanidosha $\sim$ IBS firstly. Grahani is a part of gastro-intestinal tract dealing with digestion, receptor of food and situated above Nabhi (umbilicus). ${ }^{2}$ As per Acharya Sushruta, Grahani is situated between Amashaya (stomach) and Pakvashaya (large intestine). ${ }^{3}$ So duodenumcan be considered as Grahani in Ayurveda. Normally it restrains the downward movement of undigested food and after the digestion; it releases the food through its lumen. In the abnormal condition, when it gets vitiated because of weakness of Agni it releases the food in undigested form too. ${ }^{4}$ It is characterized by Atisrushta Atibaddha Mala (loose/constipated), Trishna (thirst), Arochaka (tastelessness), Vairasya (disgeusia), Praseka (excessive salivation), Shoona Padakara (edema over hands and feet), Asthiparva Ruk (pain at small joint and bone), Chardan (vomiting), Jwara (fever) and Louha-aamagandhi Amlaudgara (sour belching with metallic smell). ${ }^{5}$ Acharaya Sushruta described it with the symptoms of edema on hand and feet, weight loss, pain in joints, urges to eat food of all taste, thirst, vomiting, fever, heat in body. ${ }^{6}$ According to Acharaya Charaka it is caused by bad habits related to diet and lifestyle i.e., Abhojanat (Excessive fasting), Ajeernabhojanat (over intake before digestion), Attibhojanaat (excessive eating), Visamasanat (due to unsalutary food), and Vegavidharana (withholding of natural urges) etc. ${ }^{7}$ Acharaya Sushruta has described it as a sequel to the intake of wrong diet after the incidence of diarrhea. ${ }^{8}$ The Shuktapaka stage (sour fermentation of food) leads to Anna-visha (poisonous edible) formation. Annavisha while, remaining in the Grahani and spread in the whole body through Rasadi Dhatu (seven major structural components that stabilize and sustain the body) produces symptoms said above.

\section{METHODS}

A 40 years old male patient with complains of Atishrastavibaddha Mala, (at once well-formed stool, at once loose stool) around 6-7 times per day along with Tiktamla udgara (bitter and sour belching), Aruchi (tastelessness), Bharakshaya (weight loss) of $20 \mathrm{~kg}$, Balakshaya (loss of physical strength), Trishna (thirst) and Parvaruk (pain in small joints) approached to OPD of PAMCH, Sriganganagar, Rajasthan. During history taking, patient was healthy before 2 years and gradually undergone in diseased condition. His weight was $42 \mathrm{~kg}$ at the time of examination. He was taking around 22 glasses of water in whole day with no satisfaction in thirst. It may be due to his stressful lifestyle and bad eating habits. He had been living far away from family due to transfer in job, and unable to get fresh homemade food. He used to eat lunch in restaurant and ordered to pack food in afternoon which he used to eat in evening. His office was in a village and 
far away from restaurant, so he used to eat cold food in evening. Patient was having antacids and antispasmodic for 1.5 years.

The case sheet Performa was prepared, contained questionnaire about lifestyle of the patient. The assessment was done, pre and post treatment, based on the symptoms gradation and analyzed by descriptive statistics. Patient written consent was taken before the study and study was carried out as per Good Clinical Practices guidelines.

\section{Personal History (Table 1)}

\section{Treatment Protocol}

Patient was treated on O.P.D. basis. Medicines were decided according to their pharmacological properties (Guna- karma), beneficial for Grahani dosha IBS.

\section{Treatment Given (Table 2 and 3)}

\section{Panchakola Udaka (Drinking Water)}

The raw drug of Panchakola [Pippali (Piper longum), Pippalimoola (Piper longum), Chavya (Piper chaba), Chitraka (Plumbago zeylanica) and Nagara (Zingiber officinale)] in equal parts was crushed or powdered coarsely, in quantity of $10 \mathrm{gm}$ and mixed in water (in quantity of 5 liter), boiled for 10 minutes. It was filtered and prepared liquid was called Panchakola Udaka. It was divided, in many doses of $250 \mathrm{ml}$, and given to patient in place of normal water, whenever he felt thirsty, for 1 month.

\section{Aarogyavardhini Vati}

2 tablets of $250 \mathrm{mg}$, b. d. orally after meal with Panchakola Udaka for 1 month; it has ingredients i.e. pure mercury, pure sulphur, Loha Bhasma (Iron ash), Abhraka Bhasma (purified Mica), Tamra Bhasma (copper ash), Triphala (Chebulic Myrobalan fruit + Belliric Myrobalan fruit + Indian gooseberry fruit), Shilajatu (mineral pitch), Guggulu (Commiphora mukul), Katuki (Picrorhiza kurrooa) and Nimba (Azadirachta indica) leaf.

Lifestyle chart given, containing Ahara (food), Vihara (lifestyle) and Achara code (customary law which prevents psycho-somatic ailments) based on Pathya (wholesome food), Apathya (unwholesome food), mentioned for diet, and Nityopayogi Dravya (dietary regimen which can be use daily), in Svastha Chatuska (chapter 5-8 of Sutra Sthana) of Charaka Samhita. The Achara like Sadvritta (good conducts), was advised. Patient was advised to take Takra (buttermilk), Masur (split lentil), Tuvara (split pigeon pea), Mudaga (green gram), Tila Tail (sesame oil), honey, Dadima (pomegranate) etc. Patient was advised for avoid heavy food, Draksha (dried grapes), milk, jaggery etc.

Follow Up: 15th day of treatment, end of the treatment (day 30) and 15 days after the treatment ended.

\section{Assessment Criteria}

\section{Inclusion Criteria}

Clinically diagnosed case of Grahanidosha $\sim$ IBS was taken for this case report.

\section{Exclusion Criteria}

Patients with uncontrolled Diabetes mellitus, hyperthyroidism, Crohn's disease, and drug induced GIT motility or constipation and hypertension were excluded.

\section{Gradation Score}

The improvement in the patient was assessed on the basis of relief in the cardinal sign and symptoms of the disease. To assess the effect of therapy, all the signs and symptoms were given scoring, depending upon their severity as below. (Table 4 )

\section{Laboratory Investigation}

CBC, blood sugar, stool test and urine test- routine and microscopic were done.

$\mathrm{Hb} \%: 11.4 \mathrm{gm} / \mathrm{dL}$

ESR: $40 \mathrm{~mm}$

BSL(R): $122 \mathrm{mg} / \mathrm{dl}$

Urine test: normal

Stool test:

Color - Yellowish

Consistency - Watery

Mucus - Absent

Bacteria - Present

Undigested food - Present

\section{RESULTS AND DISCUSSION}

Assessment of sign and symptoms of the patient, regarding Grahanidosha $\sim$ IBS, was done during each follow up (Table 5). It is shown in table number 5, that there was significant relief, in all symptoms of Grahanidosha $\sim$ IBS.

Grahanidosha $\sim$ IBS is a serious health problem seen in present era. Effective treatment is needed for this health problem in terms of long-term benefits. Antibiotics and antispasmodics are having lot of side effects. The report intended to evaluate the effectiveness of Panchakola udakaand Aarogyavardhini Vati. If Ama Dosha (undigested food matter) moves downwards and remains adhered to the Pakvashaya (large intestine), then patient should be given purgation with drugs having Agni Deepana (digestion and metabolism enhancing) property. If Dosha (regulatory functional factors of the body) spread all over the body then Shodhana (body purification therapy) is contraindicated and the principle management should be Langhana (deprivation), Pachana (enhancing digestion). ${ }^{9}$ Therefore, patient was given Langhana and Pachana treatment. The first and foremost principle of treatment of any disease is Nidana Parivarjana (avoidance of etiological factors). So, here patient was advised to have fresh cooked homemade food at two times of a day. Panchakola Udaka was given as Deepana-Pachana Dravya and Aarogyavardhini Vati as strength promoter. 
Table 1: Personal history

\begin{tabular}{|c|c|c|}
\hline Age- 40 years & Bala (Physical strength)-Avara (low) & Prakriti (somatic constitution) -Vata-pitta \\
\hline Sex- male & Sleep- inadequate & B.P.- $126 / 82 \mathrm{~mm}$ of $\mathrm{Hg}$ \\
\hline Marital status- married & Addiction- no & Weight- $42 \mathrm{Kg}$ \\
\hline Occupation- Manager & Bowel habits- irregular & Height- $156 \mathrm{c} . \mathrm{m}$. \\
\hline & Appetite- low & Pulse- $78 / \mathrm{minute}$ \\
\hline
\end{tabular}

Table 2: Ingredients of Panchakola Udaka

\begin{tabular}{|c|c|c|c|c|c|}
\hline S. No. & Ingredients & Rasa (Taste) & Guna (Properties) & Virya (potency) & Vipaka (bio transformed rasa) \\
\hline 1 & $\begin{array}{c}\text { Pippali } \\
\text { (Piper longum) }\end{array}$ & Katu & Laghu, Tikshna & Ushna & Madhura \\
\hline 2 & $\begin{array}{l}\text { Pippalimoola } \\
\text { (Piper longum) }\end{array}$ & Katu & Laghu, Ruksha & Ushna & Katu \\
\hline 3 & $\begin{array}{c}\text { Chavya } \\
\text { (Piper chaba) }\end{array}$ & Katu & Laghu, Ruksha & Ushna & Katu \\
\hline 4 & $\begin{array}{c}\text { Chitraka } \\
\text { (Plumbago zeylanica) }\end{array}$ & Katu & Laghu, Ruksha & Ushna & Katu \\
\hline 5 & $\begin{array}{c}\text { Nagara } \\
\text { (Zingiber officinale) }\end{array}$ & Katu & Laghu & Ushna & Madhura \\
\hline
\end{tabular}

Table 3: Ingredients of Arogyavardhini Vati

\begin{tabular}{|c|c|c|c|}
\hline S. No. & Ingredients & Botanical Name & Amount \\
\hline 1 & Parada (purified Mercury) & - & 1 part \\
\hline 2 & Gandhaka (purified Sulphur) & - & 1 part \\
\hline 3 & Loha Bhasma (purified Iron ash) & - & 1 part \\
\hline 4 & Abhraka Bhasma (purified Mica ash) & - & 1 part \\
\hline 5 & Tamra Bhasma (purified Copper ash) & - & 1 part \\
\hline 6 & $\begin{array}{ll} & \text { Triphala } \\
\text { a. } & \text { Amalaki } \\
\text { b. } & \text { Haritaki } \\
\text { c. } & \text { Vibhitaki } \\
\end{array}$ & $\begin{array}{ll}\text { a. } & \text { Emblica officinalis Gaertn. } \\
\text { b. } & \text { Terminalia chebula } \\
\text { c. } & \text { Terminalia bellirica }\end{array}$ & 2 part \\
\hline 7 & Shilajatu (mineral pitch) & Asphaltum & 3 part \\
\hline 8 & Guggulu (purified gum resin) & Commiphora mukul & 4 part \\
\hline 9 & Chitraka & Plumbago zeylanica & 4 part \\
\hline 10 & Katuki & Picrorhiza kurrooa & Equal of above \\
\hline 11 & Juice extract of Nimba leaf & Azadirachta indica & As per need for making pill \\
\hline
\end{tabular}

Table 4: Gradations of parameters for assessment

\begin{tabular}{|c|c|c|c|}
\hline S. No. & Clinical features & Grading & \\
\hline \multirow[t]{4}{*}{1} & \multirow{4}{*}{$\begin{array}{l}\text { Atishrasta Vibadhdha Mala } \\
\text { (At once well-formed stool, } \\
\text { at once loose stool) }\end{array}$} & Passing normal consistency stool (1 time/day) & 0 \\
\hline & & Passing stool irregular (1-2 times/day) without pain & 1 \\
\hline & & Passing stool irregular (3-4 times/day) with pain & 2 \\
\hline & & Passing stool irregular just after meal ( 5 times or more than 5 times/day) with pain & 3 \\
\hline \multirow[t]{4}{*}{2} & \multirow[t]{4}{*}{ Trishna (thirst) } & Normal thirst & 0 \\
\hline & & Mild thirst, intake water frequently & 1 \\
\hline & & Excessive thirst, but satisfied after taking a good amount of water ( $>20$ glasses) & 2 \\
\hline & & Excessive thirst, never satisfied after taking a good amount of water ( $>20$ glasses) & 3 \\
\hline \multirow[t]{4}{*}{3} & \multirow[t]{4}{*}{ Aruchi (tastelessness) } & Taking normal diet with interest & 0 \\
\hline & & taking normal diet but with no interest & 1 \\
\hline & & Food has taken forcefully & 2 \\
\hline & & Not taken a food even forcefully & 3 \\
\hline \multirow[t]{4}{*}{4} & \multirow{4}{*}{$\begin{array}{l}\text { Parvaruk (pain in small } \\
\text { joints) }\end{array}$} & No complaint & 0 \\
\hline & & Mild complain/occasionally & 1 \\
\hline & & Moderate pain, but felt after pressing the points & 2 \\
\hline & & Severe pain, and felt all time & 3 \\
\hline \multirow[t]{4}{*}{5} & \multirow{4}{*}{$\begin{array}{l}\text { Tiktamla udgara (bitter and } \\
\text { sour belching) }\end{array}$} & No complaint & 0 \\
\hline & & 1-3 days/week & 1 \\
\hline & & 3-5 days/week & 2 \\
\hline & & More than 5 days/week & 3 \\
\hline \multirow[t]{4}{*}{6} & \multirow[t]{4}{*}{ Bharakshaya (weight loss) } & No weight loss & 0 \\
\hline & & Weight loss of $1 \mathrm{~kg}$ per week with no weakness & 1 \\
\hline & & Weight loss of 1-2 kg per week with weakness & 2 \\
\hline & & Weight loss of $>2 \mathrm{~kg}$ per week with weakness & 3 \\
\hline \multirow[t]{4}{*}{7} & \multirow{4}{*}{$\begin{array}{c}\text { Balakshaya (loss of physical } \\
\text { strength) }\end{array}$} & No weakness & 0 \\
\hline & & Weakness but performs day to day activities & 1 \\
\hline & & Weakness and difficulty in performing day to day activities & 2 \\
\hline & & Cannot able to get up from bed & 3 \\
\hline
\end{tabular}


Anjali Goyal / Int. J. Res. Ayurveda Pharm. 10 (6), 2019

Table 5: Changes in sign and symptoms during each follow up

\begin{tabular}{|c|c|c|c|c|c|}
\hline S. No. & Sign and Symptoms & $\begin{array}{c}\text { Before } \\
\text { treatment }\end{array}$ & $\begin{array}{l}\text { First follow up } \\
\left(15^{\text {th }} \text { day }\right)\end{array}$ & $\begin{array}{l}2^{\text {nd }} \text { follow up or } \\
\text { after treatment }\end{array}$ & $\%$ of Relief \\
\hline 1 & $\begin{array}{l}\text { Atishrasta Vibadhdha Mala (at once well-formed } \\
\text { stool, at once loose stool) }\end{array}$ & 3 & 2 & 1 & $75 \%$ \\
\hline 2 & Trishna (thirst) & 3 & 2 & 1 & $75 \%$ \\
\hline 3 & Aruchi (tastelessness) & 2 & 1 & 0 & $100 \%$ \\
\hline 4 & Parvaruk (pain in small joints) & 2 & 1 & 1 & $75 \%$ \\
\hline 5 & Tiktamla udgara (bitter and sour belching) & 3 & 2 & 0 & $100 \%$ \\
\hline 6 & Bharakshaya (weight loss) & 2 & 1 & 0 & $100 \%$ \\
\hline 7 & Balakshaya (loss of physical strength) & 2 & 1 & 0 & $100 \%$ \\
\hline
\end{tabular}

\section{Probable Mode of Action of Panchakola Udaka}

It is a mixture of Pippali, Pippalimoola, Chavya, Chitraka and Nagara in equal parts. ${ }^{10}$ It alleviates Vata and Kapha (regulatory functional factors of the body). It has properties of Katu (pungent taste) Vipaka (bio transformed rasa), Katu Rasa and Ushna Virya (hot potency). It is very good appetizer and digestion promoter. ${ }^{11}$ A clinical study has shown that Panchakola Siddha Yavagu is effective as an appetizer. ${ }^{12}$ Pippali is rejuvenating, stimulant, expectorant, carminative, warming and decongestant. ${ }^{13}$ Chavya and Shunthi are considered as stimulants, anti-catarrhal and carminative. Chitraka promotes appetite, helps digestion. It is used for dyspepsia, piles, and skin diseases. ${ }^{14}$ Nagar (Shunthi) is stimulating, diaphoretic, expectorant, and carminative. ${ }^{15}$ Ginger is considered as an adjuvant in many Ayurveda formulas in which it enhances absorption and prevents gastrointestinal side effects. ${ }^{16}$ Hertz (1910) has observed by x-ray that very promptly following the administration of a strong carminative by mouth colon peristalsis is set up. This is a reflex action, and it tends to cause the expulsion of accumulations of intestinal gas and to overcome colic or griping. Absorption is rapid from stomach and duodenum. ${ }^{17}$ Panchakola powder with versatile properties acts synergistically and relieves inflammation, edema and restores the structures of the body to normalcy, improves appetite and relieves flatulence. ${ }^{18}$ Patient was given Panchakola in Udaka (drinking water) form so that fewer doses can be given whole of the day and effect can be enhanced by constancy.

\section{Probable Mode of Action of Arogyavardhini Vati}

The drug has been mentioned in Rasratnasamucchaya ${ }^{19}$ in the context of Kushtha (various skin diseases) and in Bhaisajyaratnavali $^{20}$ in the context of Yakritvikara (liver disorder). It acts as alternative, carminative and stomachic. ${ }^{21}$ It has ingredients i.e. pure mercury, pure sulphur, Loha Bhasma (Iron ash), Abhraka Bhasma (purified Mica), Tamra Bhasma (copper ash), Triphala (Chebulic Myrobalan fruit + Belliric Myrobalan fruit + Indian gooseberry fruit), Shilajatu (mineral pitch), Guggulu (Commiphora mukul), Katuki (Picrorhiza kurrooa) and Nimba (Azadirachta indica) leaf. It has properties like - digestive, appetizer, pathya, and cleanser of waste materials from body. ${ }^{22}$ The drug contains ingredients like Haritaki (Terminalia chebula) which is an astringent and laxative in nature. The herb Vibhitaki (Terminalia bellirica) is a laxative and a valuable remedy for digestive disorders. Another ingredient Amalaki (Emblica officinalis Gaertn.) is an antibacterial, carminative, stomachic and anti-oxidative. The mineral Shilajita is an effective agent for renewing vitality and useful in digestive disorders. The oleo-gum-resin (Guggulu) helps in Vedana Shamana (pain killer). The herb Chitraka is an effective appetizer and digestive. Aarogyavardhini Vati removes toxins from the body. ${ }^{23}$ It is beneficial in diarrhea. It cures various types of inflammation in intestine. ${ }^{24}$

- The gradation scores of weight loss, Aruchi and Tiktamlodgara, before treatment, were found 2, 2, and 3 respectively and after treatment Shifted to 0 . Relief was found $100 \%$. Patient was gained $2 \mathrm{~kg}$ of weight. No antacid required for Tiktamoldgara during or after treatment. (Table 5)

- Gradation of symptoms of Atisrashtavibaddha Mala, Trishna and Parvaruk were shifted 3, 3 and 2 respectively to 1 after treatment. It has shown marked improvement in disease. Defecation urgency just after meal was normalized. Patient was able to eat normally with no urge to stool pass after treatment. Patient was taking too much water (22 glasses) with no satisfaction but after treatment thirst was controlled. (Table 5)

- In gradation score Balakshaya (much interference with daily activities), was shifted 2 to 0 that indicated increasing working efficiency after treatment. (Table 5)

- Patient was feeling satisfied and not too much worried regarding his digestion, after treatment, shown relief in patient condition. (Table 5)

\section{CONCLUSION}

This case has been shown encouraging results. The frequency of defecation was decreased and normalized. Relief was occurred in all symptoms of thirst, weight loss, weakness etc. Patient had gained weight of $2 \mathrm{~kg}$. The drugs had no side effects. Patient had stopped antibiotics and antispasmodics. It may conclude that Mithya Aahara Vihara (improper diet and lifestyle) is the main cause for Agni Dushti, which leads to Ama Dosha and finally results into Grahani Dosha. The proactive approach need to be taken for prevention of Grahani with the planning of proper diet. It is stated that Ayurveda can be a promising alternative in Grahanidosha $\sim$ IBS. Further clinical trials are needed to establish a standard management of digestive disorders.

\section{Future Scope and Limitations}

Further study can be done on Grahanidosha IBS with large sample size. It can be used as an alternative option to modern antibiotics and antispasmodics in IBS in future.

A standard for the design, conduct, performance, monitoring, auditing, recording, analyses, and reporting of clinical trials that provides assurance that the data and reported results are credible and accurate and that the rights, integrity, and confidentiality of trial subjects are protected.

\section{REFERENCES}

1. Lovell RM, Ford AC. Global prevalence of and risk factors for irritable bowel syndrome: A meta-analysis. Clinical gastroenterology and hepatology 2012; 10(7): 712-721. https://www.cghjournal.org/article/S1542-3565(12)003084/fulltext . DOI:https://doi.org/10.1016/j.cgh.2012.02.029

2. Agnivesh, Charaka Samhita, Ayurveda-Dipika commentary by Chakrapanidutta, Chikitsa Sthana. Grahanidosha Chikitsitam adhyaya, Ch. 15, Ver. 56-57. 
Revised edition 2011. Varanasi: Chaukhambha Surbharati Prakashan; 2011. p. 517.

3. Sushruta, Susruta Samhita, Nibandha-Sangraha commentary by Dalhana, Uttara Tantra. Atisara Pratishedham adhyaya, Ch. 40, Ver. 169. Revised edition 2012. Varanasi: Chaukhambha Surbharati Prakashan; 2012. p. 709 .

4. Agnivesh, Charaka Samhita, Ayurveda-Dipika commentary by Chakrapanidutta, Chikitsa Sthana. Grahanidosha Chikitsitam adhyaya, Ch. 15, Ver. 57. Revised edition 2011. Varanasi: Chaukhambha Surbharati Prakashan; 2011. p. 517.

5. Agnivesh, Charaka Samhita, Ayurveda-Dipika commentary by Chakrapanidutta, Chikitsa Sthana. Grahanidosha Chikitsitam adhyaya, Ch. 15, Ver. 53-54. Revised edition 2011. Varanasi: Chaukhambha Surbharati Prakashan; 2011. p. 517

6. Sushruta, Susruta Samhita, Nibandha-Sangraha commentary by Dalhana, Uttara Tantra. Atisara Pratishedham adhyaya, Ch. 40, Ver. 173-175. Revised edition 2012. Varanasi: Chaukhambha Surbharati Prakashan; 2012. p. 710

7. Agnivesh, Charaka Samhita, Ayurveda-Dipika commentary by Chakrapanidutta, Chikitsa Sthana. Grahanidosha Chikitsitam adhyaya, Ch. 15, Ver. 42-44. Revised edition 2011. Varanasi: Chaukhambha Surbharati Prakashan; 2011. p. 517

8. Sushruta, Susruta Samhita, Nibandha-Sangraha commentary by Dalhana, Uttara Tantra. Atisara Pratishedham adhyaya, Ch. 40, Ver. 167. Revised edition 2012. Varanasi: Chaukhambha Surbharati Prakashan; 2012. p. 709.

9. Agnivesh, Charaka Samhita, Ayurveda-Dipika commentary by Chakrapanidutta, Chikitsa Sthana. Grahanidosha Chikitsitam adhyaya, Ch. 15, Ver. 75. Revised edition 2011. Varanasi: Chaukhambha Surbharati Prakashan; 2011. p. 518

10. Sri Bhavmishra, Bhava Prakasha Nighantu (Indian Materia Medica), commentary by Prof. K.C. Chunekar, edited by Late Dr. G.S. Pandey, Purvakhanda Misraprakarana. Ch. Haritakyadi Varga, Ver. 65. Revised edition 2010. Varanasi: Chaukhambha Bharati Academy; 2010. p. 24.

11. Sri Bhavmishra, Bhava Prakasha Nighantu (Indian Materia Medica), commentary by Prof. K.C. Chunekar, edited by Late Dr. G.S. Pandey, Purvakhanda Misraprakarana. Ch. Haritakyadi Varga, Ver. 66. Revised edition 2010. Varanasi: Chaukhambha Bharati Academy; 2010. p. 24.

12. More S.D., Dwivedi RR. A clinical study of panchakola siddha Yavagu in the management of Agnimandya. AYU. 2011; 32: 70-75. https://www.ncbi.nlm.nih.gov/pmc/ articles/PMC3215422/. DOI-: 10.4103/0974-8520.85733

13. Agnivesh, Charaka Samhita, Ayurveda-Dipika commentary by Chakrapanidutta, Chikitsa Sthana. Karprachitiyam Rasayanapadam, Ch. 1(3), Ver. 32-34. Revised edition 2011. Varanasi: Chaukhambha Surbharati Prakashan; 2011. p. 385.

14. Chopra RN, IC Chopra, Handa KL, Kapur LD. Indigenous drugs of India, Plumbago Zeylanica- pharmacological action and therapeutic uses. Part ш: drugs used in indigenous medicine, section 1: drugs of vegetable origin. Reprint edition. Kolkata: Academic publishers; 2006. p. $387 . \quad$ https://books.google.co.in/books?id=2HyC4GJ50YC\&pg

15. stuartxchange.org/Luya.html/(Zingiber officinale) Ginger/ properties, http://www.stuartxchange.org/Luya.html

16. Ramar Samy, Peter Pushpraj, Ponnampalam Gopalkrishnakone. A compilation of bioactive compounds from Ayurveda. Bio information current trends. Biomedical informatics publishing group 2008; 3(3): 100-110. https://www.ncbi.nlm.nih.gov/pmc/articles/PMC2639691/. PMCID: PMC2639691

17. Patil JM Hirlekar RS, Gide PS and Kadam VJ. Trends in floating drug delivery system. Journal of scientific and industrial research. 2006; 65: 11-21. https://pdfs.semantic scholar.org/4cd3/8112ecad3af094182f684ae103e686f2251 c.pdf. IPC code- F16K17/26.

18. Goud Panthulu Raghupathi. The effect of Ayurvedic drugs when used as disease modifying anti rheumatic drugs (DMARD's) in Amavata (Rheumatoid Arthritis). IJRAP 2012; 3(1): 27-31. https://www.researchgate.net/ publication/287179423

19. Shastri Ambikadatta. Rasaratna Samuchchya. Visarpa Kushtha Chikitsa adhyaya, Ch. 20, Ver. 87. $9^{\text {th }}$ edition. Varanasi: Chaukhamba Sanskrit Publisher; 1994. p. 400.

20. Sen Kaviraj Govinda Das. Bhaisajyaratnavali, Siddhipada Hindi commentary, edited by Prof. Siddhinandana Mishra. $1^{\text {st }}$ edition 2012. Klomarogadhikarah, Ch. 54, Ver.117. Varanasi: Chaukhamba Surbharati Prakashana; 2012. p. 871.

21. Maharaja Krishnananda Ji. Rasatantrasara and Siddhayoga Sangraha. Kharaliya Rasayana, Ch. 8. $1^{\text {st }}$ edition 2015. Ajmer, Rajasthan: Krishna Gopal Ayurveda Bhavana; 2015. p. 250.

22. https://www.ayurtimes.com/ Arogyavardhini Vati benefits, uses, dosage and side effects. https://www.ayurtimes.com/ arogyavardhini-vati-benefits-uses-side-effects/

23. Kumar G, Srivastava A, Sharma SK, Gupta YK. Safety evaluation of an Ayurvedic medicine, Arogyavardhini vati on brain, liver and kidney in rats. Journal of Ethnopharmacology $\quad 2012 ; \quad 140$ : 151-160. https://www.sciencedirect.com/science/article/pii/S037887 4112000050. DOI- https://doi.org/10.1016/j.jep. 2012.01.004

24. Sarashetti RS, Simpi CC, Sandeep NM, Kanthi VG. Screening of free radical scavenging activity of Arogyavardhini vati. IJRAP 2013; 4(4): 555-559. https://www.researchgate.net/publication/269847071. DOI-10.7897/2277-4343.04421

\section{Cite this article as:}

Anjali Goyal. A case study to evaluate the efficacy of Panchakola udaka and Aarogyavardhini vati in Grahani dosha with special reference to Irritable Bowel Syndrome. Int. J. Res. Ayurveda Pharm. 2019;10(6):95-99 http://dx.doi.org/10.7897/22774343.1006132 every effort has been taken to verify the accuracy of the content published in our Journal. IJRAP cannot accept any responsibility or liability for the site content and articles published. The views expressed in articles by our contributing authors are not necessarily those of IJRAP editor or editorial board members. 